\title{
Hedefe Yönelik Kemoterapi Illaçlarına Bağlı Akneiform Döküntü ve Eșlik Eden Diğer Dermatolojik Yan Etkiler: Retrospektif Bir Değerlendirme
}

\author{
Acneiform Eruption and Other Dermatologic Side Effects Induced by \\ Targeted Cancer Therapy: A Retrospective Analysis
}

\section{Kurtuluș Didem Yazganoğlu, Can Baykal}

İstanbul Üniversitesi Tıp Fakültesi, Deri ve Zührevi Hastalıklar Anabilim Dalı, İstanbul, Türkiye

\section{Özet}

Amaç: Epidermal büyüme faktörü reseptörü (EBFR) inhibitörleri bașta akneiform (püstüler, papülopüstüler) döküntü olmak üzere birçok dermatolojik yan etkiye yol açabilmektedir. Nadiren hedefe yönelik bașka kemoterapi ilaçları da benzer bir püstüler döküntüye neden olabilir. Çalıșmamızda çoğu son yıllarda kullanıma giren bu ilaçlara bağlı olarak gözlemlediğimiz bașta akneiform döküntü olmak üzere dermatolojik yan etkilerin değerlendirilmesi amaçlandı.

Gereç ve Yöntem: Mayıs 2007 ve Nisan 2011 tarihleri arasında kemoterapi ilaçlarına bağlı akneiform döküntü tanısı konulan 23 hastanın poliklinik kayıtları retrospektif olarak incelendi. Akneiform döküntüye neden olan ilaçlar, döküntünün klinik özellikleri, eșlik eden diğer dermatolojik yan etkiler ve hangi tedavi seçeneklerinin kullanılmıș olduğu araștırıldı. Dermatolojik yan etkilere bağlı olarak kemoterapinin kesilip kesilmediği değerlendirildi.

Bulgular: Akneiform ilaç döküntüsüne neden olan ilaçların bașında 21 hastada etken olan erlotinib ve setuksimab gibi EBFR inhibitörleri yer alıyordu. Everolimus ve irinotekan ile bevasizumabın birlikte kullanımı birer hastada etkendi. Döküntü tüm hastalarda yüzü etkilerken bunu gövde, boyun ve saçlı deri izliyordu. Yüzün birçok bölgesi tutulurken göz çevresi çoğunlukla sağlam kalmıștı. Kseroz ve paroniși sık eșlik eden dermatolojik bulguları oluștururken, iki hastada geç dönemde kaș, kirpik kıllarında uzamaya rastlanmıștı. Takibi yapılabilen tüm hastalarda akneiform döküntü ve paroniși topikal veya sistemik antibiyotiklerle veya akne vulgaris ve rozasea tedavisinde yer alan bașka ilaçlar ile önemli ölçüde kontrol altına alınmıștı ve kemoterapinin kesilmesine gerek kalmamıștı. Sonuç: Deri ve Zührevi Hastalıklar uzmanlarının kemoterapi ilaçlarının özgün döküntüleri konusunda bilgi sahibi olması ve hastalara doğru yaklașması kemoterapinin idamesinin sağlanması açısından kritik bir öneme sahiptir. Kemoterapi kullanımına bağlı akneiform döküntü özellikle yüzü ilgilendirirken, göz çevresi sağlam kalır. Kseroz, paroniși ve trikomegali eșlik eden diğer dermatolojik bulgulardır. (Türkderm 2012; 46: 84-9)

Anahtar Kelimeler: Epidermal büyüme faktörü reseptörü inhibitörleri, hedefe yönelik kemoterapi, akneiform döküntü, paroniși, kseroz, trikomegali

\section{Summary}

Background and Design: Epidermal growth factor receptor (EGFR) inhibitors may cause different adverse cutaneous reactions including acneiform (pustular, papulopustular) eruption. Rarely, other specific targeted cancer therapy agents may cause similar pustular eruptions. The aim of this study was to evaluate the adverse skin reactions, mainly acneiform eruptions caused by these chemotherapeutic agents.

Material and Methods: We retrospectively analyzed the data of 23 patients who developed acneiform eruption due to chemotherapeutic agents between May 2007 and April 2011. The drugs causing acneiform eruption, clinical features of eruption, other associated dermatologic adverse reactions and the treatment modalities used for the acneiform reaction were noted. Results: EGFR inhibitors such as erlotinib and cetuximab were the main drugs causing acneiform eruption in 21 patients. Everolimus and bevacizumab in combination with irinotecan were responsible in two patients. The eruption occurred on the face in all patients. The trunk, neck and the scalp were other affected body parts in some patients. The periorbital area on the face was generally spared. Xerosis and paronychia were the main associated adverse cutaneous reactions. Trichomegaly was another finding in two patients. The patients, who could have been followed, responded to topical or systemic antibiotics, or some medications for acne vulgaris/rosacea. Chemotherapy could be continued in all patients.

Yazışma Adresi/Address for Correspondence: Dr. Kurtuluș Didem Yazganoğlu, Istanbul Üniversitesi I stanbul Tip Fakültesi, Deri ve Zührevi Hastalklar Anabilim Dall, Istanbul, Türkiye Tel.: +90 2126352939 E-posta: karadidem@yahoo.com Geliş Tarihi/Received: 21.06.2011 Kabul Tarihi/Accepted: 09.09.201 1

Türkderm-Deri Hastalıkları ve Frengi Arșivi Dergisi, Galenos Yayınevi tarafindan basılmıștır.

Turkderm-Archives of the Turkish Dermatology and Venerology, published by Galenos Publishing. 
Conclusion: Dermatologists need to know the specific eruptions occurring with chemotherapy drugs, especially EGFR inhibitors in order to develop the best approach without discontinuation of cancer therapy. Acneiform eruptions due to chemotherapeutics are most commonly seen on the face sparing periorbital area. Other reactions including mainly xerosis, paronychia and trichomegaly can also occur. (Turkderm 2012; 46: 84-9) Key Words: Epidermal growth factor receptor inhibitors, targeted chemotherapy, acneiform eruption, paronychia, xerosis, trichomegaly

\section{Giriş}

2000 'li yıllarda Onkoloji alanında kullanımı giderek artan epidermal büyüme faktörü reseptörü (EBFR) inhibitörlerinin daha önceden tanımlanmış tüm ilaç döküntülerinden farklı bir tabloya neden oldukları gösterilmiştir. Bu hedefe yönelik kemoterapi ilaçlarının dermatolojik yan etki (deri toksisitesi) oranı çok yüksektir ve başta püstüler (akneiform, papülopüstüler) ilaç döküntüsü olmak üzere birkaç farklı tip deri veya deri eki reaksiyonuna aynı anda veya uzun bir süreç içinde yol açabilirler1-5. Daha nadir olarak, sitotoksik ilaçların dışında kalan başka kemoterapi ilaçlarına bağlı olarak da püstüler döküntülere rastlanabilmektedir. Kliniğimizde kemoterapi ilaçlarına bağlı püstüler yan etki ile ilgili saptayabildiğimiz ilk kayıt 2007 yılındadır. Özellikle EBFR inhibitörü ilaçların kullanım sıklığındaki artışla ilişkili olarak giderek sık karşılaşılan bu reaksiyonların klinik özelliklerini araştırmak amacıyla kliniğimizde son 4 yılda kemoterapi ilaçlarına bağlı akneiform döküntü tanısı konulan hastaların değerlendirilmesi planlandı.

\section{Gereç ve Yöntem}

Mayıs 2007- Nisan 2011 tarihleri arasında İstanbul Tıp Fakültesi Deri ve Zührevi Hastalıkları kliniğinde kemoterapi ilaçlarına bağlı akneiform döküntü tanısı konulan tüm hastaların dosya kayıtları retrospektif olarak gözden geçirilerek demografik özellikleri, tedavi almalarını gerektiren malinite tipi, kullandıkları kemoterapi ilacı tipi, akneiform döküntünün yerleşimi, eşlik eden diğer dermatolojik yan etkiler, aldıkları dermatolojik tedaviler ve kemoterapinin devamının sağlanıp sağlanamadığı retrospektif olarak değerlendirildi. Toplam 23 hastada akneiform erüpsiyon gelişmişti. Bu hastalar akneiform erüpsiyon nedeniyle dermatoloji kliniğine doğrudan başvurmuş veya primer hastalığı nedeniyle takip eden onkologlar tarafından konsülte edilmişlerdi. Hastaların 20'sine başlanan dermatolojik tedavi dosyalarında belirtilmişti. Tedavi verildikten sonra kontrolü yapılan 10 hasta bulunmaktaydı. Bunların takip süreleri 1-16 ay arasında değişmekteydi.

\section{Bulgular}

Kemoterapi ilaçlarına bağlı akneiform döküntü tanısı konan 23 hastanın verileri Tablo 1'de gösterilmiştir. Hastaların 17'si erkek, 6'sı kadındı ve yaşları 26-86 arasında değişiyordu (ortalama yaş: $54,13 \pm 15,44)$. Döküntü 11 hastada erlotinib, 10 hastada setuksimab, 1 hastada everolimus, 1 hastada irinotekan ve bevasizumabın birlikte kullanımı ile ilişkilendirildi. Akneiform döküntü (Şekil 1a-i, 2a-e) tüm hastalarda yüzü etkilerken, gövde 17 hastada, saçlı deri 10 hastada, boyun 10 hastada, ekstremiteler 7 hastada tutulmuştu. Göz çevresi tutulumu açısından üç hastada ayrıntılı kayıtlar yetersiz iken, kalan 20 hastanın hiçbirinde göz çevresi tutulumunun olmaması dikkat çeken bir özellik idi (Şekil 1d). Hastaların 17'sinde püstüler lezyonlara başka dermatolojik bulgular eşlik ediyordu. Birinde plantar bölgede de

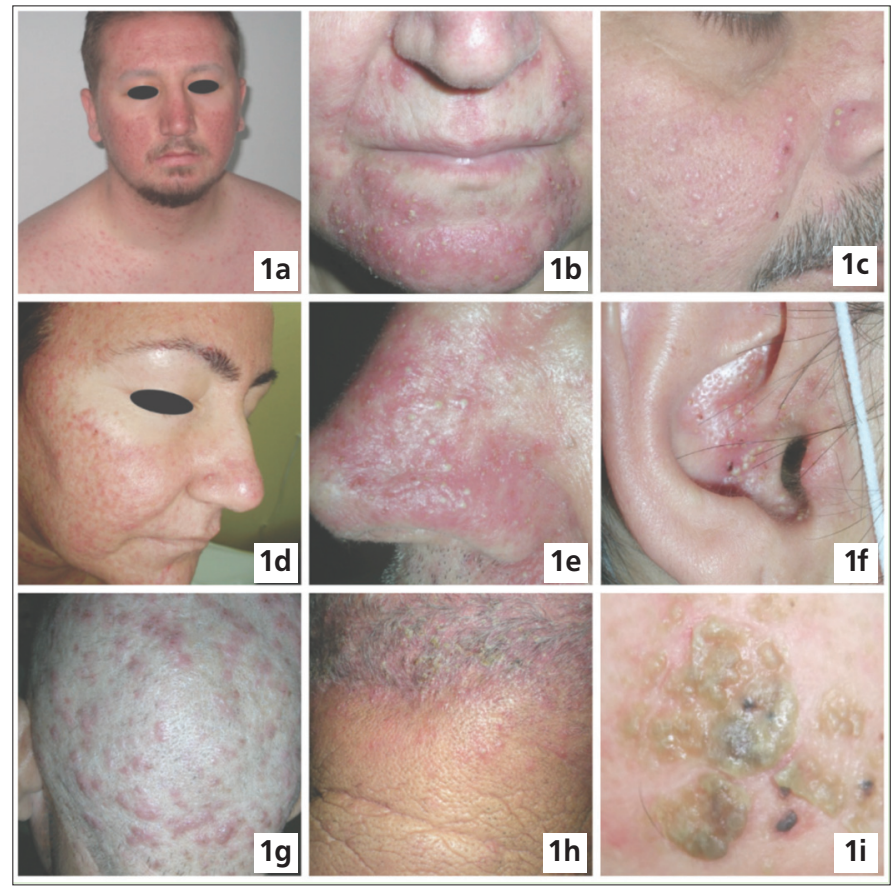

Şekil 1. Akneiform döküntü; yüz, boyun, gövde (a), çene (b), yanak (c), göz çevresinin sağlam kalması (d), burun (e), kulak kepçesi (f), saçlı deri tutulumu (g), saçlı deride krutlanma (h), yüzde kurutlanma (i): sırasıyla olgu 9, 4, 19, 16, 11, 13, 22, 3, 21.
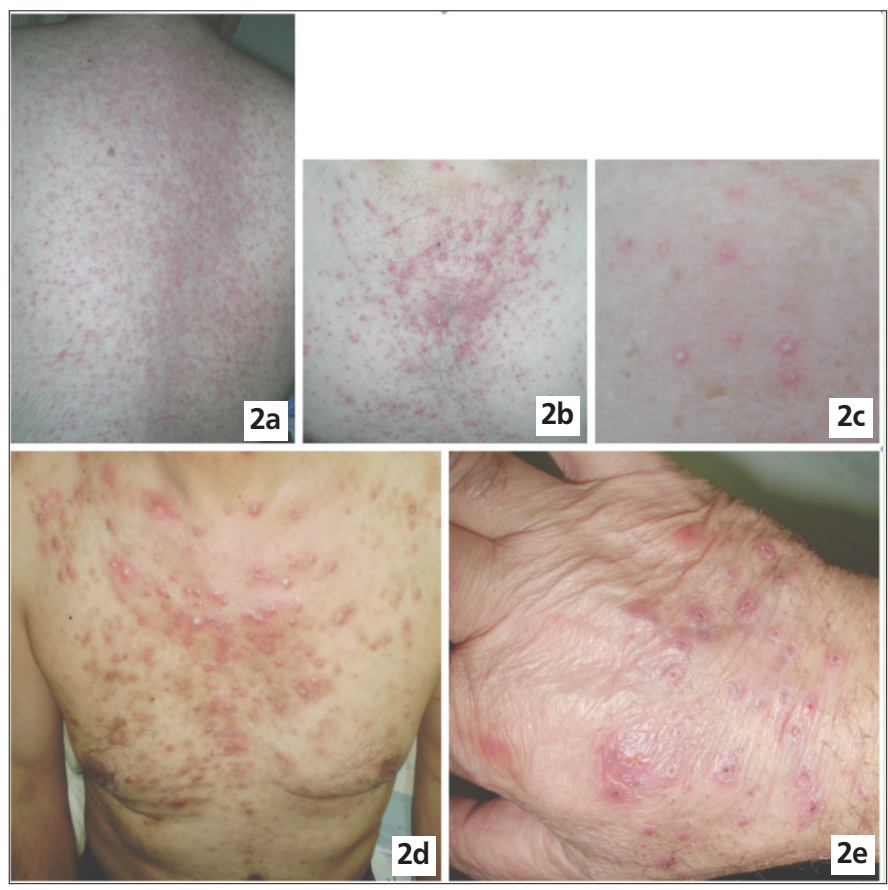

Şekil 2. Akneiform döküntü; gövde tutulumu (a-c), papülopüstüler lezyonlar ve fronkül benzeri nodüler lezyonların birlikteliği (d-e): sırasıyla olgu 18, 7, 20, 23, 15. 
püstüller vardı. Üç hastada püstüller dışında erken dönem fronkü benzeri görünümde nodüler lezyonlar vardı. Paronişi (Şekil 3a-3d) 7 hastada bir veya birkaç tırnak çevresinde bulunuyordu. Bunlardan birinde hipertrofik granülasyon dokusu paronişiye eşlik ediyordu (Şekil 3d). Iki hastada parmak uçlarında fissürler (Şekil 3e, f), 8 hastada gövde veya ekstremitelerde kseroz vardı (Şekil 3g). Bir hastada karın bölgesinde operasyon insizyon sikatrisi üzerinde kemoterapiye başlanmasını takiben piyojenik granülom benzeri hipertrofik granülasyon dokusu oluşması gözlenmişti. Bir hastada ağız içinde aftöz ülserler (Şekil 3h) saptanmıştı. Bir hastada tedavinin üçüncü ayında kaş ve kirpiklerde uzama ve artış, bir hastada ise altıncı ayında kaş ve kirpiklerde uzama ve kıvırcıklaşma (Şekil 3i) başlamıştı.

Hastalarımızdan üçünün kayıtlarında püstüler veya paronişyal lezyonların kontrol altına alınabilmesi için hangi ilacı kullandıkları belirtilmemişti. Geri kalan 20 hastadan 15'i bu lezyonlara yönelik olarak tek başına veya topikal ilaçlar ile birlikte sistemik antibiyotik tedavileri kullanmıştı (Şekil 4a-d). Beş hasta ise sadece topikal tedavi kullanmıştı. Hastaların hiçbirinde dermatolojik yan etkiye bağlı olarak kemoterapinin tamamen kesilmesi önerilmemişti. Toplam 10 hastada 1-16 ay arasında değişen takip süresinde birkaç kez muayene yapı Imıştı. Bunlar arasında sistemik antibiyotik tedavisi kullanan sekiz hastanın tümünde de tedaviye olumlu yanıt alınmıştı.

\section{Tartışma}

Kemoterapi ilaçlarına bağlı akneiform döküntünün en iyi bilinen nedeni EBFR inhibitörleridir. Bu ilaç grubunda başıı monoklonal antikorlar olan setuksimab ve panitumumab, tirozin kinaz inhibitörleri olan gefitinib ve erlotinib yer alır1-5. Ulusal Dermatoloji literatüründe setuksimab tedavisine bağlı akneiform döküntü gelişimi ile ilgili iki olgu bildirisi bulunmaktadır6,7. Yukarıda sayılan ilaçlar dışında diğer bazı hedefe yönelik kemoterapi ilaçlarına bağlı olarak da benzer bir

\section{Tablo 1. Kemoterapi ilaçlarına bağlı akneiform döküntü gelişen hastaların klinik özellikleri}

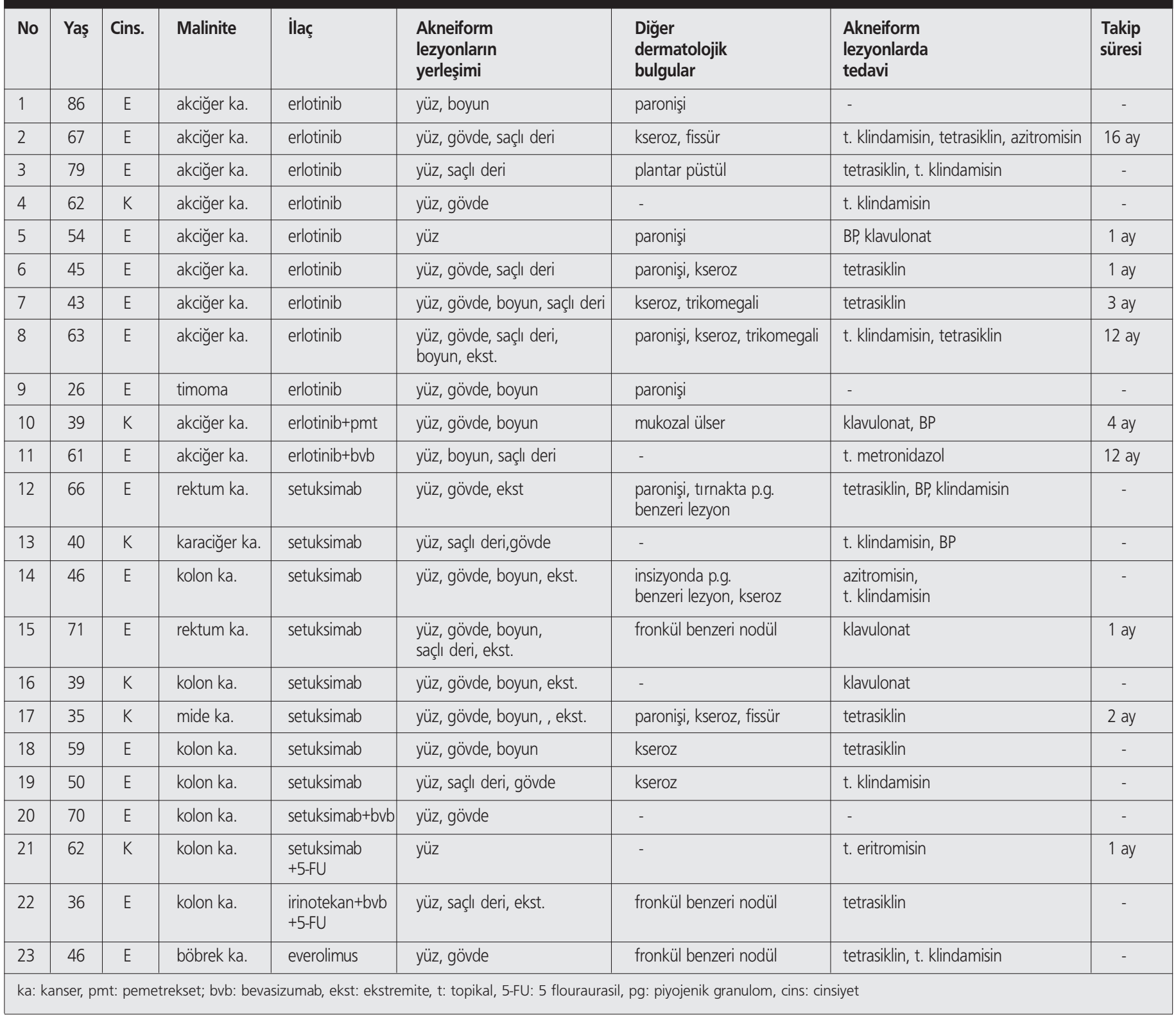




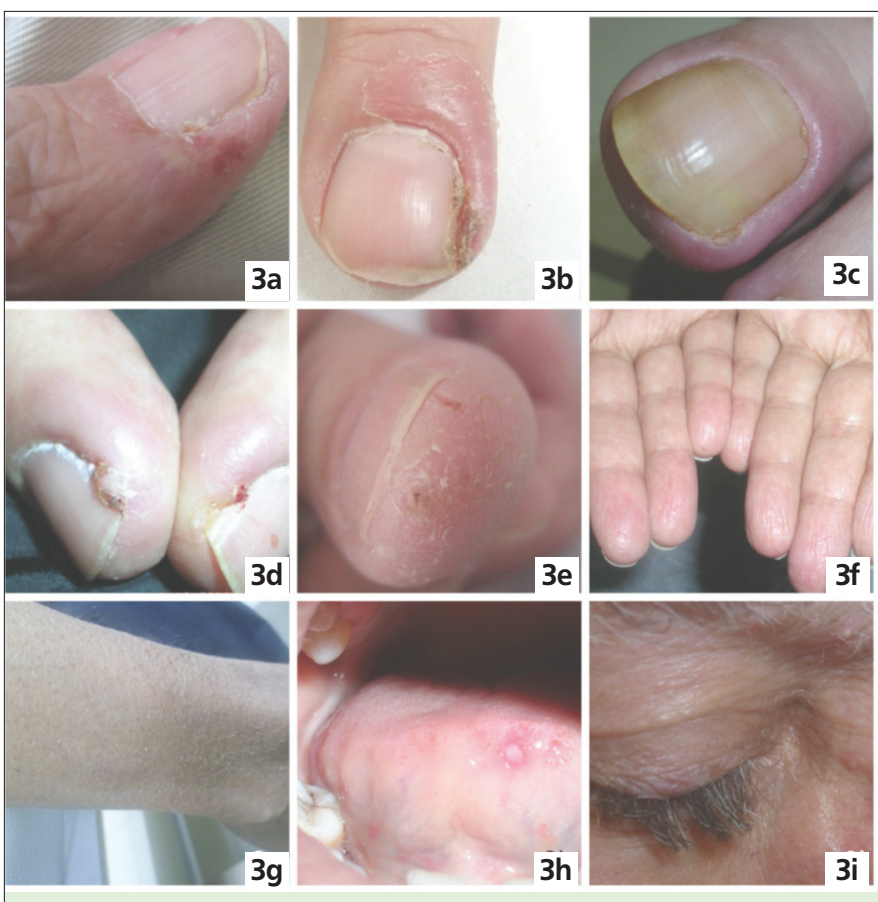

Şekil 3. Paronişi (a-c), paronişi ve hipertrofik granülasyon dokusu birlikteliği (d), parmak uçlarında fissürler (e-f), kseroz (g), mukozal ülser (h), kirpik uzaması (i): sırasıyla olgu 1, 6, 5, 12, 14, 17, 2, 10, 8.

döküntü gözlenebilir. Çalışmamıza dahil edilen 23 hastanın 21'inde döküntüden erlotinib ve setuksimab gibi EBFR inhibitörleri, 1 hastada everolimus, 1 hastada ise irinotekan ve bevasizumab sorumlu olarak düşünüldü. Bu ilaçların tümü klasik sitotoksik ajanların dışında kalıyordu. Çalışmamızdaki hastalarda setuksimab gastrointestinal kanserler (mide, karaciğer, kolon, rektum), erlotinib akciğer kanseri ve lenfositik timoma, irinotekan kolon kanseri, everolimus böbrek kanseri için kullanılmıştı. Bevasizumab üç hastada kullanılırken, hiçbirinde tek başına kullanı Imamıştı. İki hasta bu ilaçlarla beraber 5flourourasil de kullanmakla birlikte benzer dermatolojik yan etkileri olmayan bu klasik sitotoksik kemoterapi ilacı değerlendirmeye alınmadı.

EBFR, tip I reseptör kinaz ailesi üyesi olup epidermisin bazal tabakasındaki prolifere olan, farkılaşmamış keratinositlerde ve kıl folikülünde eksprese edilmektedir2,3. Tümör büyümesi, hücre proliferasyonu, apopitoz, anjiyogenez, hücre motilitesi ve metastaz süreçlerinde rol oynamaktadır. Daha çok solid kanserlerin ileri evrelerinde kullanılan EBFR inhibitörleri tümör proliferasyonunu engelleyerek gerçekleştirdikleri asıl etkileri yanında deride EBFR yolunu da bloke ederek keratinosit proliferasyonu ve diferansiyasyonunu, kıl folikülünün normal diferansiyasyonunu ve gelişimini bozarak çok sayıda deri reaksiyonuna neden olurlar4. Bu açıdan akneiform döküntünün hipersensitive reaksiyonu değil, farmakolojik bir etki olduğu öne sürülmüştür8. Bunun dışında EBFR inhibitörleri ile bildirilen diğer deri reaksiyonları arasında kseroz, ekzema, paronişi, saç ve tırnak değişiklikleri, daha az sıklıkla ise hiperpigmentasyon, trikomegali, telanjiektazi ve mukozal aft yer alır1-4.

Everolimus mTOR inhibisyonu yapan bir ilaçtır. mTOR inhibisyonu yapan ilaçlar, akneiform döküntü ve aftöz ülserler gibi dermatolojik yan

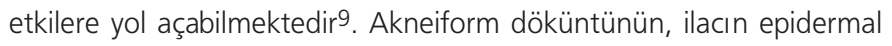
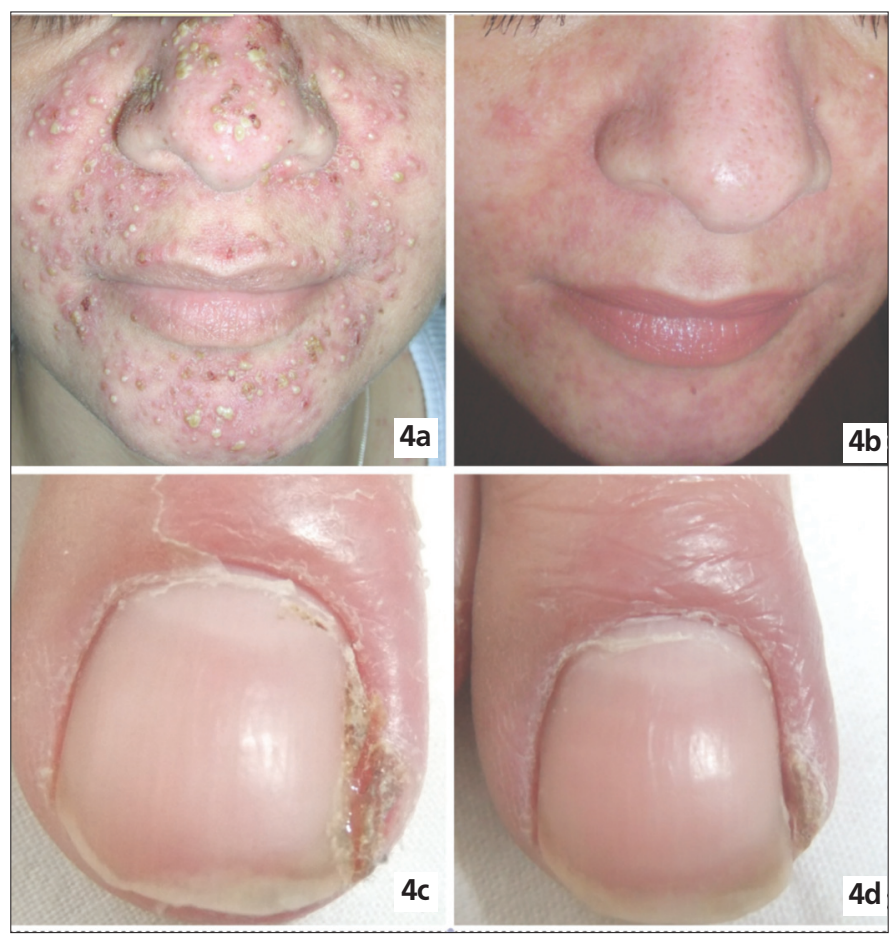

Şekil 4. Sistemik antibiyotik tedavisine yanıt; akneiform döküntüde gerileme (a-b), paronişide gerileme (c-d): sırasıyla olgu 10, 6 .

büyüme faktörü inhibisyonuna yol açması ile ilişkili olduğu öne sürülmüştür9. Dolayısıyla EBFR inhibitörleri ile gelişen akneiform lezyonlar ile klinik olarak benzer bir döküntü görülmektedir. Her iki ilaç grubuna bağlı gelişen döküntülerin tedavisi de aynıdır ${ }^{9}$ Çalışmamızda bir hastada everolimusa bağlı akneiform döküntü görüldü.

Bevasizumab vasküler endotelyal büyüme faktörü (VEBF) inhibitörü olup az sayıda olguda akneiform döküntü yapıcı yan etkisi bildirilmiştir10,11. VEBF, kıl folikülü hücreleri, keratinositler ve endotelyal hücreler için büyüme faktörü olduğundan bu ilaçla ortaya çıkan dermatolojik yan etkilerin EBFR inhibitörlerine bağlı akneiform döküntü ile aynı mekanizma sonucu oluştuğu öne sürülmüştür10. Hastalarımızın biri setuksimab, biri de erlotinibe ek olarak bevasizumab kullanıyordu. Bevasizumabın deri döküntüsü yapıc yan etkisi daha nadir olduğundan akneiform döküntünün ön planda EBFR inhibitörleri veya ikisinin birlikte kullanımı ile ilişkili olabileceği düşünüldü.

İrinotekanın tek başına akneiform döküntü yapı cı etkisi bilinmezken setuksimab ile birlikte kullanıldığında şiddetlendirici olduğu öne sürülmüştür3,12. Çalışmamızda akneiform döküntü gelişen bir hasta irinotekan ve bevasizumabı birlikte kullanıyordu. Bu hastada döküntünün tek başına bevasizumaba mı yoksa iki ilacın beraber kullanılmasına mı bağlı olduğu kesin söylenemedi.

EBFR inhibitörlerine bağlı dermatolojik yan etkiler içinde akneiform döküntü en sık (\%75-100) ve en erken görülen reaksiyondur2-4,13. Tanısı hemen her zaman öykü ve klinik özelliklere dayanılarak konur. Püstüller, ilaç kullanımının genellikle ilk 1-3 haftası içinde başlar2,3,5. Hastalarımızın hepsinde bu lezyonlar ilk 2 hafta içinde ortaya çıkmıştı. Püstüller sterildir, bakteri veya mantar açısından kültür yapılmasına gerek yoktur4,14. Akne vulgaristen farklı olarak eşlik eden komedon yoktur ${ }^{1-5}$. Patolojik ve etyolojik olarak akne vulgaristen farklı olması nedeniyle "akne, akne benzeri ve akneiform" terimleri yerine 
"papülopüstüler reaksiyon" terimi kullanılması5,15 önerilmekle birlikte, birçok kaynakta "akneiform döküntü" olarak bahsedilmektedir1-4,6,7. Ayırıcı tanıya girdiği başııca sistemik kortikosteroid kullanıma bağlı gelişen klasik akneiform ilaç döküntüsünden farklı olarak daha akut ve inflamatuvardır. Kaşıntı bazen bulunabilir, bu da hem akne vulgaristen hem de kortikosteroid aknesinden ayrımında yararlıdır1,4. Akut generalize ekzantematöz püstülozdan farklı olarak ise kıvrım yerleri tutulumu belirgin değildir, püstüller birleşme eğilimi göstermezler ve ateş yükselmesine neden olmaz. Şiddeti doza ve tedavi süresine bağımlı olup, yüksek doz ilaç kullananlarda daha şiddetli olabilir4,5. Bu reaksiyonun belirgin olduğu hastalarda ilacın tedavi edici etkisinin de daha fazla olduğu ve bir sağkalım belirteci olarak kabul edilebileceği şeklinde bir görüş de vardır2,4. EBFR inhibitörlerinin dermatolojik yan etkilerinin şiddetinin derecelendirilmesinde sıklıkla bu ilaçların yan etkilerine spesifik olmayan derecelendirme kriterleri (National Cancer Institute Common Terminology Criteria for Adverse Events ${ }^{16}$ ) kullanılmakla beraber, bu konuda kesin bir standart belirlenememiştir 5,13 . Sadece EBFR inhibitörlerinin yol açtığı dermatolojik yan etkileri değerlendirmeye yönelik spesifik bir derecelendirme sistemi de son yıllarda geliştirilmiştir ${ }^{17}$. Çalışmamızda dermatolojik yan etkiler için derecelendirme yapılmadı, sadece püstüler lezyonların olduğu bölgeler belirtildi.

EBFR inhibitörlerine bağlı püstüler döküntü en sık seboreik bölgelerde gözlenir1,14. Yüz (Şekil 1a-d), boyun (Şekil 1a), saçlı deri (Şekil 1g) ve gövde (Şekil 1a, 2a,b) çalışmamızda en sık tutulan bölgelerdi. Yüzde burun (Şekil 1e), yanaklar (Şekil 1c), çene (Şekil 1b) ve kulak (Şekil 1f) daha sık tutulmaktaydı. Yüz tutulumu hastalarımızın tümünde mevcut iken, göz çevresi tutulumu açısından üçünde ayrıntılı kayıtlar yetersiz idi; kalan 20 hastanın hiçbirinde göz çevresi tutulumunun olmaması dikkat çeken bir özellik idi (Şekil 1d). Püstüler lezyonlar gerilerken krutlar ön planda olabilmekteydi (Şekil 1h-i). Papülopüstüler lezyonların yüz dışında daha çok gövde üst kısımda yoğunlaştığı dikkat çekti (1a, 2b), fakat alt kısımlarında da gözlendi (Şekil 2a). Hastalarımızın 17'sinde gövdedeki püstüller yüz tutulumuna eşlik ediyordu. Kollar tutulsa bile tutulum genellikle çok şiddetli değildi. Püstüllerin birleşme eğilimleri azdı (Şekil 2c). Hastalarımızın birinde plantar bölgede de püstüller vardı. Üç hastamızda küçük püstüllerin yanı sıra fronkül benzeri büyük lezyonlara da rastlandı (Şekil 2d-e). Bunların 2'si EBFR inhibitörleri dışında farklı gruptan kemoterapi ilacı kullanmaktaydı.

Akneiform döküntü özellikle yaygın olduğunda hastaların yaşam kalitesini etkilemekte ${ }^{13,18}$ ve tedaviye uyumunu engellemektedir ${ }^{13}$ Sekonder infeksiyon açısından da risk oluşturur4,14. Dolayısıyla çoğu zaman tedavi edilmesi gerekir ancak kanıta dayalı verilere göre belirlenmiş standart bir tedavi yoktur3,13. Lezyonlar steril olmakla birlikte topikal ve sistemik antibiyotiklerden ve akne vulgaris veya rozase tedavisinde kullanılan bazı ilaçlardan yararlanır2,3. Öyle ki bu reaksiyona yönelik profilaktik antibiyotik tedavisi yapılması şeklinde bir öneri de vardır ${ }^{19}$. Hastalarımızda lezyonların şiddetine göre tedavi düzenlenmiş ve 15 hastaya sistemik antibiyotikler kullanılmıştı. Sistemik antibiyotik tedavisi sonrası kontrol muayeneleri yapılabilen 8 hastada hemen her zaman kısa sürede olumlu yanıt alınmıştı (Şekil 4a-b). Hastalarımızdan döküntüsü şiddetli olmayan 5 tanesine sistemik tedaviye gerek görülmeksizin sadece topikal tedavi kullanılmıştı.

EBFR inhibitörlerine bağlı tırnak ve tırnak çevresi toksisitesi daha çok kseroz, parmak uçlarında deskuamasyon, fissürler, akut paronişi, tırnak batması ve piyojenik granülom benzeri hipertrofik granülasyon dokusu gelişimi şeklinde karşımıza çıkar20. Paronişi oranı yaklaşık \%10-15 arası bildirilmiş olup2,4, çalışmamızda 7 hastada gözlenmiştir (Şekil 3a-d). Tedavi başlanmasını takiben yaklaşık 1 ay sonra, bazen 6 aya varan süre içerisinde yani püstüler lezyonlara göre daha geç ortaya çıkan bir bulgudur4,20. Paronişi sıklıkla birden fazla el tırnağını ve ayak başparmak tırnağını ilgilendirir4, çalışmamızda da genellikle az sayıda tırnağı ilgilendiriyordu. Paronişi, infeksiyon ile ilişkisiz olabilse de topikal ve sistemik antibiyotiklere, bazen de lokal kortikosteroid tedavisine olumlu yanıt verir4,20. Şiddetli tutulumda, özellikle periungual granülasyon dokusuna yönelik cerrahi girişimler de yapılabilir20. Çalışmamızda akneiform lezyonlar ve paronişiye yönelik tek sistemik antibiyotik uygulanmıştı ve izlenebilen hastalarda ilaç kullanım sürecinde başarılı sonuç alınmıştı (Şekil 4c-d).

EBFR inhibitörü kullananların yaklaşık \%35'inde kseroz gelişmektedir1,3,4. Yüz, gövde, ekstremiteler gibi akneiform döküntünün etkilendiği bölgelerde olmakta, ancak daha yaygın olarak gözlenmektedir4. Çalışmamızdaki hastaların 8'sinde gövde veya ekstremitelerde kseroz (Şekil 3e-g) gözlendi.

Hastalarımızın birinde EBFR inhibitörlerinin nadir yan etkilerinden olan damak bölgesinde küçük aftöz lezyonlar (Şekil 3h) saptanmıştı. Ancak bu hasta erlotinib ile beraber pemetrekset de kullandığı için, oral aftın erlotinibe mi yoksa bu ilaca mı bağlı olduğuna karar verilemedi. Diğer nadir yan etkilerden hiperpigmentasyon gözlenmezken, hastalarımızın tedavi öncesi durumları bilinmediğinden telanjiektazi konusunda değerlendirme yapılamadı. Bir hastada kemoterapiye başlanmasını takiben püstüler döküntüye ek olarak gövdedeki operasyon insizyon sikatrisi üzerinde hipertrofik granülasyon dokusu ortaya çıtı.

Kirpiklerin aşırı uzama, kıvırcıklaşma ve sertleşmesi (trikomegali) EBFR inhibitörlerinin iyi bilinen yan etkilerinden biri olup tedavi başlanmasından yaklaşık olarak 2 ile 5 ay sonra ortaya çıkmaktadır 4,14. Saç, kaş ve ekstremite kıllarında da kıvırcıklaşma, uzama, incelme veya kırılmaya eğilim olabilmekte, özellikle kadınlarda daha çok fark edilen hipertrikoz gözlenebilmektedir14,21. Setuksimab kullanan hastalarda trikomegali oranının \%30'un üzerinde olduğu bildirilmiştir ${ }^{14}$. Erlotinib kullanan iki hastamızda tedavinin 3. ve 6 . ayında başlamak üzere kaş ve kirpiklerinde uzama, artma veya kıvırcıklaşma gibi değişiklikler gözlendi (Şekil 3i).

Çalışmamızdaki hastaların önemli bölümü ilaç reaksiyonunun erken döneminde görülmüş ve daha çok ilk tedaviye verdikleri yanıt gözlenmiştir. Dermatolojik tedavi kesildiğinde akneiform lezyonlar ve paronişi nüks edebilir. Uzun süre (12-16 ay) ilaç kullanan 3 hastada püstüler lezyonlar ve/veya paronişi şiddetleri azalmış olarak devam ediyordu. Bununla birlikte çalışmamızda uzun süre takip edilen hasta sayısı kısıtlı olduğundan söz konusu kemoterapi ilaçlarının uzun dönem dermatolojik yan etkileri konusunda yorum yapmak güçtür. EBFR inhibitörleri ile döküntüye bağlı ölümün var olup olmadığını araştırmak amacıyla literatürdeki prospektif çalışmaları irdeleyen bir derlemede 8998 kanser hastası içinde döküntüye bağlı ölüm gözlenmediği bildirilmiş ancak döküntüye sekonder olarak gelişen şiddetli infeksiyonların görülebileceği belirtilmiştir18. Bir hastada setuksimabın tek başına22, bir diğerinde ise minosiklinle beraber kullanımı sonrası toksik epidermal nekroliz gelişimi gözlenmekle birlikte23, bunların birinde ölüm bildirilmiştir22

EBFR inhibitörleri ile olan döküntü çoğunlukla tedavi kesilmesini gerektirmeyen bir yan etki olmakla birlikte, tedaviye ara vermede başlıca göz önüne alınması gereken, hastanın yaşam kalitesini ne 
kadar etkilediğidir. Döküntünün geçici olduğu ve EBFR inhibitörleri ile tedavinin devamında şiddetinin azalabileceği akılda tutulmalıdır¹. Çalışmamız polikliniğimize ayaktan başvuran hastaları içermektedir, bu açıdan çok hafif ve çok şiddetli döküntüler ile karşılaşılmamış olabilir. Takip süreleri 1-16 ay arasında değişen 10 hastamızda papülopüstüler lezyonlar nedeniyle tedavi kesilmesi tarafımızdan önerilmemekle birlikte, bazı hastalarda Onkoloji uzmanları tarafından tedaviye 1-2 haftalık kısa aralar verilmişti. Döküntünün tanınması ve doğru yaklaşım, kemoterapinin kesintiye uğramasını önlemesi açısından da önem taşır.

\section{Sonuç}

EBFR inhibitörlerine bağlı dermatolojik yan etkiler özellikle Medikal Onkoloji bölümü olan hastanelerde görev yapan Deri ve Zührevi Hastalıklar uzmanlarının sık karşılaştığı sorunlardır. EBFR inhibitörleri dışında everolimus ve bevasizumab da püstüler ilaç reaksiyonu nedenleri arasında yer alır. Kemoterapi ilaçlarına bağı akneiform döküntü en sık yüzde yerleşmekte, bunu gövde ve saçlı deri izlemektedir. Yüzü tutan püstüler döküntünün göz kapaklarını etkilememesinin EBFR inhibitörlerine bağlı akneiform döküntünün önemli bir klinik özelliği olduğu söylenebilir. Hastalarımızda püstüler döküntüye eşlik eden belirtilerin başında kseroz ve paronişi gelmektedir. EBFR inhibitörlerine bağlı yan etkiler lezyonların şiddetine göre değişen uygun tedavilerle kontrol altına alındığında kemoterapinin kesilmesi gerekmemektedir.

\section{Kaynaklar}

1. Galimont-Collen AFS, Vos LE, Lavrijsen APM, Ouwerkerk J, Gelderblom H: Classification and management of skin, hair, nail and mucosal side-effects of epidermal growth factor receptor (EGFR) inhibitors. Eur J Cancer 2007;43:845-51.

2. Ehmann LM, Ruzicka T, Wollenberg A: Cutaneous side-effects of EGFR inhibitors and their management. Skin Therapy Lett 2011;16:1-3.

3. Segaert S, Tabernero J, Chosidow $\mathrm{O}$, et al: The management of skin reactions in cancer patients receiving epidermal growth factor receptor targeted therapies. J Dtsch Dermatol Ges 2005;3:599-606.

4. Hu JC, Sadeghi P, Pinter-Brown LC, Yashar S, Chiu MW: Cutaneous side effects of epidermal growth receptor inhibitors: clinical presentation, pathogenesis, and management. J Am Acad Dermatol 2007;56:317-26.
5. Agero ALC, Duzsa SW, Benvenuto-Andrade C, et al: Dermatological sideeffects associated with the epidermal growth factor receptor inhibitors. J Am Acad Dermatol 2006;55:657-70.

6. Kuş S, Uygur T, Candan i: Kolorektal kanser tedavisinde kullanılan setuksimaba bağlı akneiform erüpsiyon. Turkderm 2006;40:B85-7.

7. Arıcan Ö, Önver N: Setuksimab tedavisine bağlı akneiform erüpsiyon: bir olgu sunumu. Turk J Dermatol 2011;5:29-32.

8. Cowen EW: Epidermal growth factor receptor inhibitors: a new era of drug reactions in a new era of cancer therapy. J Am Acad Dermatol 2007;56:514-7

9. Campistol JM, de Fijter JW, Flechner SM, et al: mTOR inhibitor-associated dermatologic and mucosal problems. Clin Transplant 2010;24:149-56.

10. Keenan BP, Abuav R: Acneiform eruption in a patient receiving bevacizumab for glioblastoma multiforme. Arch Dermatol 2010;146:577.

11. Amselem L, Diaz-Llopis M, Garcia-Delpech S, et al: Papulopustular eruption after intravitreal bevacizumab (Avastin ${ }^{\circledR}$ ). Acta Ophthalmol 2009;87:110-1.

12. Cunningam $D$, Humblet $Y$, Sienna $S$ et al. Cetuximab monotherapy and cetuximab plus irinotecan in irinotecan-refractory metastatic colorectal cancer. N Engl J Med 2004;351:337-45.

13. Hassel JC, Kripp M, Al-Batran S, Hofheinz RD: Treatment of epidermal growth factor receptor antogonist-induced skin rash: results of a survey among German oncologists. Onkologie 2010;33:94-8.

14. Ocvirk J, Cencelj S: Management of cutaneous side-effects of cetuximab therapy in patients with metastatic colorectal cancer. J Eur Acad Dermatol Venereol 2010;24:453-9.

15. Lacouture ME, Melosky BL. Cutaneous reactions to anticancer agents targeting the epidermal growth factor receptor: a dermatology-oncology perspective. Skin Therapy Lett 2007;12:1-5.

16. National Cancer Institute (NCl). Common Terminology Criteria for Adverse Events v3.0 (CTCAE). http://ctep.cancer.gov/protocolDevelopment/ electronic_applications/docs/ctcaev3.pdf. Son erişim tarihi 4 Haziran 2012.

17. Lacouture ME, Maitland ML, Segaert S, et al: A proposed EGFR inhibitor dermatologic adverse event-specific grading scale from the MASCC skin toxicity study group. Support Care Cancer 2010;18:509-22.

18. Jatoi A, Nguyen PL: Do patients die from rashes from epidermal growth factor receptor inhibitors? A systematic review to help counsel patients about holding therapy. Oncologist 2008;13:1201-4.

19. Scope A, Agero ALC, Dusza SW, et al: A randomized double-blind trial of prophylactic oral minocycline and topical tazarotene for cetuximab-associated acne-like eruption. J Clin Oncol 2007;25:5390-6.

20. Fox LP: Nail toxicity associated with epidermal growth factor receptor inhibitor therapy. J Am Acad Dermatol 2007;56:460-5.

21. Alexandrescu DT, Kauffman CL, Dasanu CA: Persistent hair growth during treatment with EGFR inhibitor erlotinib. Dermatol Online J 2009;15:4.

22. Lin WL, Lin WC, Yang JY, et al: Fatal toxic epidermal necrolysis associated with cetuximab in a patient with colon cancer. J Clin Oncol 2008;26:2779-80.

23. Lee SS, Chu PY: Toxic epidermal necrolysis caused by cetuximab plus minocycline in head and neck cancer. Am J Otolaryngol 2010;31:288-90. 